\title{
Assessment of coconut fibers for textile applications
}

Adriana Pacheco Martins ${ }^{1}$, Regina Aparecida Sanches ${ }^{1}$

\author{
${ }^{1}$ Escola de Artes Ciências e Humanidades, Universidade de São Paulo. Av. Arlindo Bétio, 1000, Parque Ecológico do \\ Tietê, Ermelino Matarazzo, CEP: 03828-080, São Paulo, São Paulo, Brasil. \\ email: adrianapachecomar@gmail.com, reginasanches@usp.com
}

\begin{abstract}
Brazil is the fourth larger producer in coconut fruit in the world. However, the industry processes only a small portion of coconut byproducts, which have caused serious environmental problems. The purpose of this article is to test an alternative for the recovery of coconut byproduct. In a series of experiments, recovered coconut fibers (coir) were treated to be employ in textile application. After initial classification and sampling, the fine coconut fibers were subjected to a simultaneous scouring and pre-bleaching process in a mild alkali solution together with hydrogen peroxide $\left(\mathrm{H}_{2} \mathrm{O}_{2}\right)$. The fibers were first subjected to this treatment for 10 minutes at $80^{\circ} \mathrm{C}$ and then again for 20 minutes at the boiling point. The samples were then treated with a cationic softener for 10 minutes at $60^{\circ} \mathrm{C}$. After this process, the physical and mechanical properties were measured and values proved not to be statistically significant. The article indicates some of the main obstacles when handling coconut fiber for textile applications and reveals that besides elongation, softness and homogeneity are essential for coconut fibers spinning. Findings in this investigation showed some improved results in relation to the previous literature in two aspects: Firstly, because the treatment did not harm the fibers quality; secondly, because due to the treatment the coconut fibers could be arranged in fibrous strands, which facilitated spinning and weaving for use in textile applications.
\end{abstract}

Keywords: coconut fiber, coir, scouring, softening, textile.

\section{INTRODUCTION}

Brazil produces nearly 3 million tonnes of coconut fruits a year. Coconut trees (Cocos nucifera L.) are cultivated mainly in tropical countries such as Indonesia, the Philippines, India, and Brazil [1], but the industries of food, beverage and cosmetics process coconut fruits worldwide [2]. The coconut agro-industry generates an inexorable and valuable byproduct, which is abundant and low-cost biomass. The lack of specific regulations for managing coconut waste hinders the proper collection and allocation of this material for industrial exploitation.

Unlike the past, when the industry of coconut fiber has been dedicated to low value products, in the last decades many studies testify the suitability of coconut biomass such as pith and fibers (coir), in the production of high valued proposals [3, 4]. Some of these proposals are for the use of coconut fibers as polymeric composites [5], bio-composites [6], cellulose nanocrystals [7], geotextiles [8], bio-ethanol [9], and as absorbent of industrial wastewaters containing radioactive components [10] and mercury, which is common in the oil and gas industry [11].

In Brazil, most of the coconut byproduct is dumped in landfills where they use up a significant amount of space. The biodegradation of coconut shells is long, of approximately eight years [12]. Coconut landfilling generates methane $(\mathrm{CH} 4)$, that if not recovered for energy production, it contributes to the greenhouse effect [13].

This article proposes an alternative for the recovery of coconut byproduct by employing coconut fibers in a textile application. For that, it proposes a method that is based on conventional techniques of textile production. The objective is to identify some of the main difficulties for the usage of coconut fibers in textile applications, and in the future compare the proposed method to other techniques more technologically advanced and sustainable. The pre-patented method [14] proposed consists of a sequence of wet treatments that is environmentally friendly, mild and effective without harming the coconut fibers. Besides, the method proposed facilitated the spinning and weaving of a plain textile sample.

The remaining of this article continues in Section 2 by relating the coconut fiber morphology and the standard procedures performed both in coir and cellulosic textile industry. Section 3 describes the details of 
the proposed method. Section 4 presents and discusses the results. Finally, the article closes by presenting conclusions and suggesting future studies in Section 5.

\section{LITERATURE REVIEW}

\subsection{Coconut fiber morphology}

Coconut fibers are obtained from the mesocarp of coconut shells and correspond to $30 \%$ of the entire fruit [15]. Coconut shells range from 30-45 cm in length and from 15-20 cm in diameter [16]. Green coconuts weigh approximately $2 \mathrm{~kg}$ [17]. Coconut rusk is a lignocellulosic material that corresponds to $80-85 \%$ of the fruit weight [18]. In Asia, the extraction of coir by the retting method is common [19]. Differently, Brazilian producers prefer entirely mechanical extraction methods [20,21].

Coconut fibers are highly lignified [22], and their chemical composition varies according to the agroclimatic conditions and the maturity of the fruit [23]. Coconut fibers account for approximately $32 \%$ of lignin, $45 \%$ of cellulose, $20 \%$ of hemicelluloses, and $1.3 \%$ of ashes [24]. They are yellowish brown, with an average length of approximately $15 \mathrm{~cm}$, and fineness of 14-24 micrometers [19].

\subsection{Preliminary treatments on coconut fibers and cellulosic textile materials}

Standard procedures applied to coconut fibers are the cleaning and softening with the objective of partially remove the lignin and thus, improve the tactility and the spinning. For commercial reasons, the bleaching procedure is advisable after alkaline-based treatment [25]. Although sodium hydroxide $(\mathrm{NaOH})$ is the most common softening agent, it provokes a loss of fiber strength [22]. A typical recipe of coir bleaching consists of a liquor ration 1:20 of a solution containing $8 \mathrm{~g} / \mathrm{l}$ of hydrogen peroxide $\left(\mathrm{H}_{2} \mathrm{O}_{2}\right)$ and $5 \mathrm{~g} / \mathrm{l}$ of sodium silicate. The liquid is kept under constant agitation at a temperature of $80-90^{\circ} \mathrm{C}$ for 60 minutes, rinsed in cold water and dried in the shade [15].

The spinning of coconut fiber is complicated to be performed industrially. This procedure is frequently undergone manually due to the fibers inability to generate continuous strands and due to fibers lack of cohesiveness (varied finesse and length). The textile industry of coir virtually segments the production into woven and non-woven textiles, where the last is considered more industrially feasible [26].

Scouring is a preparatory process on cellulosic fiber textiles, which objective is to remove the impurities such as organic leftovers, natural wax, and pectin [27]. It prepares the textile surface to achieve satisfactory performance in the subsequent stages like dyeing and finishing. Commonly, an alkali solution is added to ionic or nonionic detergent to slow the action of the alkali. After the scouring, the bleaching is undergone to remove the color and to preserve the cellulose. $\mathrm{H}_{2} \mathrm{O}_{2}$ is an option of bleaching agent that assists the effluent oxidation by making the wastewaters less hazardous than the discharge of chlorine-based bleaching [28]. Combining different chemical processes in one is suitable to save costs such as in time, labor, electricity, steam, water, and discharge. Chemical softening is also required for cellulosic textiles to improve smoothness, flexibility, and suppleness on the surface [29].

Biological treatment on retted and unretted coir fibers proved to be successful for softening, thinning, whitening, and improving mechanical strength [30]. Biological and enzyme-based treatments are preferable for environmental purposes, and they apply to virtually all wet procedures, both to coir and to other cellulosic textiles.

A broad diversity of enzymes is available for pre-treatment of cellulosic fibers and textiles, and present advantages toward chemical products such as, they exempt high-temperature solutions and chemical solvents. Examples of enzymes and their applications are; cellulases for softening and promoting "worn" effect on denim, amylases for removing warp starch, lipases as detergents, pectinases for cleaning and peroxidases for rinsing after reactive dyeing and removing the color and toxic compounds of wastewater [29].

Plasma-based treatment is an option of more sustainable procedure, once it requires no water. Experiments with argon plasma jet on coconut fibers resulted in the increase of absorption capacity by $45 \%$ of mass in-crease after wetting. The improvement on the hydrophilicity property occurred because of the reduction of noncellulosic components (lignin, hemicellulose, and waxes) after the plasma treatment and thus, it exposed larger parts of cellulose on fiber's surface [31]. Plasma treatments generate physical and chemical changes in fibers' morphology that are favorable both for textile and composite purposes [32].

Advanced methods of availing coconut byproduct biomass as a textile material explore other ways of producing fibers. Researchers developed fibers out of coconut rusks' activated charcoal, which apply to highperformance textiles [33]. Similarly, COSTA et al. [34] developed extruded continuous artificial fibers out of 
cellulose obtained from sugarcane straw. Because such fibers present high absorption capacity, they are compatible with medical applications.

\section{MATERIALS AND METHODS}

Traditionally, the industry undergoes wet treatments such as scouring, bleaching and softening on textile materials already knitted or woven, due to feasibility issues. However, this study deliberately opted to directly treat in loose coconut fibers to test whether this would best prepare the material for the spinning phase.

\subsection{Sample collection and preparation}

Loose green coconut fibers were donated from a fiber recovery industry (Pós-Coco) in São Paulo where they were mechanically extracted from their shells. Fibers of $15 \mathrm{~cm}$ in average length were visually classified according to a fineness criterion to ensure that the raw material was relatively homogenous in size. The finest fibers and averaging 12 centimeters in length were selected for this study and divided into three groups:

Group 1: Samples of fibers that were not wet treated, as control samples

Group 2: Samples of fibers that received full wet treatment, as pilot samples

Group 3: Samples of fibers used for wastewater effluent comparison

After selection, 30 grams of fibers from Groups 2 and 3 were separately placed inside different textile bags (60 yarns/ $\mathrm{cm}$ of polyester yarn filament) each and closed with an overlock stitch to keep the fibers aggregated in each bag throughout the wet treatment.

\subsection{Simultaneously scouring and pre-bleaching}

A solution of $3.5 \mathrm{ml}(2.5 \mathrm{ml} / \mathrm{L})$ of $\mathrm{NaOH}$ at a concentration $20^{\circ} \mathrm{Bé}$, was added to $1 \mathrm{~g} / \mathrm{L}$ of a nonionic detergent, $\mathrm{pH}$ approximately 8 (Kieralon Jet $\mathrm{B}-$ Basf). This detergent had previously been diluted with $1 \mathrm{~g} / 10 \mathrm{ml}$ of water; therefore $15 \mathrm{ml}$ was used and combined with $7.5 \mathrm{ml}(5 \mathrm{ml} / \mathrm{L})$ of $\mathrm{H}_{2} \mathrm{O}_{2}$ at a concentration of $35 \%$ when prepared in $1500 \mathrm{ml}$ water. The bag holding $30 \mathrm{~g}$ of fine fibers of Group 2 was transferred to an aluminum pot containing the detergent for the fiber/solution ratio to be 1:50. These were shaken for 10 minutes at $80^{\circ} \mathrm{C}$ and then again for 20 minutes at the boiling point. Upon completion, the bag containing the Group 2 fibers was rinsed in tap water for 2 minutes at $60^{\circ} \mathrm{C}$ and then again at $45^{\circ} \mathrm{C}$ to remove the remainder of the chemicals. The same procedure was undergone on Group 3 fibers without the addition of $\mathrm{H}_{2} \mathrm{O}_{2}$. Both solutions wastewaters were separately saved for later analysis.

\subsection{Softening}

A solution was prepared by mixing 5\% (of material weight) of cationic industrial softener (Sapamina OC Hunstman), $\mathrm{pH}$ 3.5-4.5 in 1,500 $\mathrm{ml}$ water. The softener had previously been diluted with $1 \mathrm{~g} / 10 \mathrm{ml}$ of water, so $15 \mathrm{ml}$ of softener were used. The bag containing the Group 2 fibers was transferred to a pot containing the solution, for the fiber/solution ratio to be 1:50. These were kept in the solution for 10 minutes at $60^{\circ} \mathrm{C}$. No further rinsing was performed on the fibers to keep great softness degree and favor the spinning. According to the manufacturer, this softener can be combined with a cationic and nonionic product, and it has a high degree of exhaustion and low wastewater contamination.

\subsection{Fiber drying}

The drying of the material was carried out in two stages. First, the bag containing the Group 2 fibers was transferred to a $3 \mathrm{~kg}$ capacity centrifuge machine at a rotation of $1200 \mathrm{rpm}$ to remove any solution excess. Subsequently, the bag was kept for 15 minutes at $120^{\circ} \mathrm{C}$ in a laboratory dryer (LTF-8-2293 Mathis Ltda.) to complete the drying process.

\subsection{Fiber characterization}

The chemical characterization of Group 1 fibers based on figures provided by fibers supplier. Its fibers experiments were conducted in the laboratories of Instituto de Pesquisas Tecnológicas (IPT). Physical properties of Gruops 1 and 2 fibers were characterized by calculating their linear density. Mechanical properties were identified by testing fibers' tenacity and elongation. Visual and hand comparisons were also performed in both fiber samples. 


\subsubsection{Linear density}

Fibers of Group 1 and 2 were stored for $48 \mathrm{~h}$ at $20^{\circ} \mathrm{C}$ and a relative humidity of $65 \%$ following ISO 139 [35]. After that time, 50 samples of fibers from each group were weighed on an analytic scale (ED124S - Sartorius), and their length was measured with a stainless steel ruler as indicated in Bayer - Fibras 100\% [36]. The linear densities were determined by calculating the rate between fiber's weight and length, according to an adaptation of the method suggested in ISO 1973 [37] and ASTM D3776-96 [38].

\subsubsection{Mechanical testing to determine tenacity and elongation}

The tenacity and elongation of both samples (Group 1 and 2) were measured according to ASTM D 3822 [39]. It used the "Instron" Universal Testing machine model 5940 with $10 \mathrm{~N}$ pull strength, rubber clamps measuring $2.5 \times 2.5 \mathrm{~cm}, 25 \mathrm{~mm}$ of distance between the clamps (gauge) and $6 \mathrm{~mm} / \mathrm{min}$ of speed.

\subsection{Statistical comparison of physical and mechanical properties values}

Statistical comparison of two samples by hypothesis test was calculated using the results of the tests performed and described in 3.5.1 and 3.5.2. The criteria considered were: the mean $(\mu)$ and standard deviation $\left(\sigma^{2}\right)$ of linear density (tex), tenacity (cN/tex), and elongation $(\%)$. Thereby, $\mathrm{H}_{0}: \mu_{1}=\mu_{2}$ (null hypothesis) and $\mathrm{H}_{1}: \mu_{1} \neq \mu_{2}$ (alternative hypothesis).

The confidence interval allows making conclusions about the mean values (as $\mu_{1}<\mu_{2}$ or $\left.\mu_{1}>\mu_{2}\right)$ as well as conclusions about the differences between them $\left(\mu_{1}-\mu_{2}\right)$. This test enables the superior $(\mathrm{L})$ and the inferior $(\mathrm{U})$ thresholds to be determined, and the population parameter $(\Theta)$ was set in the Equation 1 according to DALLY et al. [40]:

$$
P(L \leq \theta \leq U)=1-\alpha
$$

The interval $\mathrm{L} \leq \Theta \leq \mathrm{U}$ is the confidence interval of $\Theta$ with a percentage of 100 (1- $\alpha)$. After calculating the variances $\sigma_{1}$ and $\sigma_{2}, H_{1}$ can be tested by the following Equation 2:

$$
Z_{0}=\frac{\overline{y_{1}}-\overline{y_{2}}}{\left(n_{1}\right)^{\frac{1}{2}}+\frac{\sigma_{2}}{\left(n_{2}\right)^{\frac{1}{2}}}}
$$

If $\mathrm{H}_{0}$ is true, the distribution $\mathrm{Z}_{0}$ is $\mathrm{N}(0.1)$, the critical region is found using a normal distribution, and $\mathrm{H}_{0}$ is rejected if $\left|\mathrm{Z}_{0}\right|>\mathrm{Z}_{\alpha / 2}$, where $\mathrm{Z}_{\alpha / 2}$ is the percentage of the superior threshold $\alpha / 2$ of the normal distribution [41].

$$
\bar{y}_{1}-\bar{y}_{2}-Z_{\frac{\alpha}{2}} \frac{\sigma_{1}}{\left(n_{1}\right)^{\frac{1}{2}}}+\frac{\sigma_{2}}{\left(n_{2}\right)^{\frac{1}{2}}} \leq \mu_{1}-\mu_{2} \leq \bar{y}_{1}-\bar{y}_{2}+Z_{\frac{\alpha}{2}} \frac{\sigma_{1}}{\left(n_{1}\right)^{\frac{1}{2}}}+\frac{\sigma_{2}}{\left(n_{2}\right)^{\frac{1}{2}}}
$$

Equation 3 determines the confidence interval 100(1- $\alpha)$ for the difference between the means $\left(\mu_{1}-\mu_{2}\right)$. Where $\bar{y}_{1}$ represents mean values of Group 1 fibers properties, and $\bar{y}_{2}$ accounts for mean values of the Group 2 fibers properties. It was considered a significance level of 0.05 .

\subsection{Spinning and weaving}

Fibers of the Group 2 were spun in an electric spinning wheel. Another yarn made out of $100 \%$ unbleached cotton fiber ( 3 cables and title 12) was arranged as warp whereas the coconut fibers yarn (from Group 2) was arranged as weft in the loom. The loom produced two samples of plain-woven textiles.

\section{RESULTS AND DISCUSSION}

\subsection{Chemical treatments}

Table 1 presents the chemical characterization of Group 1 fibers. Simultaneous scouring and pre-bleaching allow partial concentrations of lignin present on the surface of the cellulosic materials to be eliminated, and thus they reduce the brownish color of the fibers [15]. The complete removal of lignin in coconut fibers is 
only possible through complex methods such as those practiced in cellulose pulping production or biorefinery [42), but these methods disrupt fiber structure [25]. For bioethanol production purpose, CABRAL et al. [9] reduced in $10 \%$ the amount of lignin and increased in $30 \%$ the amount of cellulose. They treated $5 \mathrm{~g}$ of coconut fiber in a solution containing $100 \mathrm{ml}$ of water with $5 \%$ of $\mathrm{NaOH}$ autoclaved at $121^{\circ} \mathrm{C}$ during 40 minutes.

Coconut fiber surface is full of impurities and other elements. When alkali treatment is undergone for clean-ing and softening coconut fibers, it toughens up fibers surface due to the crystallization of $\mathrm{NaOH}$, which impacts in the increase of fiber's tensile strength. Although the increase in roughness, alkali treatment is beneficial to expose larger amounts of cellulose on the fiber, the tensile strength proportionally diminishes after subsequent treatment with $\mathrm{H}_{2} \mathrm{O}_{2}$ [43]. The present study proposes a mild treatment that partially removed amounts of lignin present on fiber's surface while preserving the structure of the fiber.

Table 1: Chemical characterization of untreated coconut fibers in Group 1 according to PARRA [N44].

\begin{tabular}{l|l|l|l|l}
\hline ASH & $\begin{array}{l}\text { LIGNIN SOLUBLE } \\
\text { IN ACID (\%) }\end{array}$ & $\begin{array}{l}\text { LIGNIN SOLUBLE IN } \\
\text { ACID AT 205 NM (\%) }\end{array}$ & $\begin{array}{l}\text { TOTAL EXTRACTED IN- } \\
\text { DICHLOROMETHANE (\%) }\end{array}$ & HOLOCELLULOSE \\
\hline $2.34+-0.06$ & $30.98+-0.72$ & $0.074+-0.012$ & $0.19+-0.07$ & $68.76+-0.37$ \\
\hline
\end{tabular}

The wastewater generated from the scouring not treated with $\mathrm{H}_{2} \mathrm{O}_{2}$ in Group 3 fibers produced a dark brown liquid in contrast to light yellow wastewater generated from the simultaneous scouring and prebleaching (added to $\mathrm{H}_{2} \mathrm{O}_{2}$ ) method performed in Group 2 fibers. The darkening effect also occurs on the fibers surface after alkali treatment alone [22]. Wastewaters from coir fibers treated in 1:10 of fiber in $\mathrm{H}_{2} \mathrm{O}_{2}$ at $0.075 \%$ for $24 \mathrm{hs}$ after bioextraction proved to be environmentally harmless after analyzing their $\mathrm{pH}$, chemical oxygen demand (COD), and total organic carbon (TOC) [45]. Similar analysis should be performed in the wastewaters of this study to provide accurate information about the toxicity of the proposed method.

After softening and drying, the visual and manual comparison indicated that the fibers of Group 2 were softer and lighter in color than Group 1 fibers. Authors agreed about the dimensions variability common in coconut fiber, both among themselves in a bunch and also over the length of a single fiber [22, 45, 46]. Prior to the selection this study found Group 1 fibers ranging from 5 and 123 tex in linear density. Brazilian native coconut fibers have oval cross section that can vary from 0.250 to $0.411 \mathrm{~mm}$ in diameter [46]. The average linear density of the Group 2 fibers (see Table 2) showed that agents contained in the scouring and pre-bleaching method contributed to reducing the fiber thickness by $17 \%$ compared to Group 1 fibers. Similarly GOULART SILVA et al. [46] verified a weight loss after treatment with 5 wt $\%$ of $\mathrm{NaOH}$ solution during 48-72 hours, as well as VARMA et al. [22] whose weight loss after alkali treatment $\left(10 \% \mathrm{NaOH}\right.$ at $30^{\circ} \mathrm{C}$ during 4 hours) impacted also in the reduction of $16 \%$ in the diameter of fine fibers and even more in thicker fibers.

\subsection{Mechanical tests}

Table 2 compares physical and mechanical properties of treated and untreated coconut fibers demonstrates that the elasticity percentage of Group 2 fibers kept superior to other values found in previous literature.

Table 2: Physical and mechanical properties of untreated and treated coconut fibers.

\begin{tabular}{l|l|l|l|l|l|l|l|l}
\hline & \multicolumn{3}{l}{ UNTREATED } & \multicolumn{3}{l}{ TREATED } \\
\hline PROPERTY & GROUP 1 & [45] & [46] & [22] & GROUP 2 & [45] & [46] & [22] \\
\hline$\mu$ Lenght (mm) & 120 & 100 & $>50$ & $>50$ & - & - & - & - \\
\hline Thickness (mm) & - & 0.30 & 0.250 & 0.270 & - & - & 0.290 & 0.227 \\
\hline$\mu$ Linear Density (tex) & 12 & - & - & - & 10 & - & - & - \\
\hline$\sigma$ Linear Density (tex) & 3.39 & - & - & - & 4.31 & - & - & - \\
\hline
\end{tabular}




\begin{tabular}{|c|c|c|c|c|c|c|c|c|}
\hline$\mu$ Tenacity (cNtex) & 17 & - & - & 19.96 & 19 & - & - & 18.37 \\
\hline$\sigma$ Tenacity (cNtex) & 5.18 & - & - & - & 8.92 & - & - & - \\
\hline Tensile Strenght (Mpa) & - & 172 & 91 & - & - & 148 & 98 & - \\
\hline$\mu$ Elongation (\%) & 46 & 31.90 & 27 & 28.80 & 43 & 40.10 & 30 & 27.40 \\
\hline$\sigma$ Elongation $(\%)$ & 17.76 & - & - & - & 17.17 & - & - & - \\
\hline
\end{tabular}

In comparison to synthetic fibers the average value of the tenacity and elongation of Group 1 fibers were similar to the values of the same properties in low-density polyethylene: 4.4-17.7 cNtex and 20-80\% respectively [47].

\subsection{Statistical comparison of physical and mechanical properties values}

The results of statistical tests strongly indicated that hypothesis $\mathrm{H}_{0}$ was valid because $\mathrm{Z}_{0}>\mathrm{Z} 0.025$ in the three parameters tested (see Table 3). Although a reduction of fiber strength after chemical treatment is already expected $[15,22]$ and it must be controlled to avoid damages in the spinning process [30], this study found values of linear density, tenacity, and elongation for Group 2 fibers that were statistically not significant to compromise the fibers' quality.

Table 3: Significance level (CV) and confidence interval $\left(\mathbf{Z}_{\mathbf{0}}\right)$ values of the hypothesis test on coconut fiber physical properties.

\begin{tabular}{l|l|l|l|l}
\hline & $\mathbf{Z}_{0}$ & $\mathbf{C V} \%_{1}$ & CV\% & \\
\hline Linear Density & 0.57 & 28.04 & 41.56 & 1.96 \\
\hline Tenacity & -1.52 & 29.70 & 46.92 & 1.96 \\
\hline Elongation & 0.58 & 38.14 & 39.91 & 1.96 \\
\hline
\end{tabular}

\subsection{Spinning and weaving}

The elongation at break is an essential property for textile fibers because it improves the twisting in the production of yarns either of the same or blended with other fibers. The elongation is even more crucial for warp yarn, which bears the greater tension during the weaving, for that reason the elongation of warp yarn should not be too low [30].

The treatment implemented provided enough softness that the fibers could be arranged in continuous strands and spun in a regular twisted yarn.

The spinning yielded $1.3 \mathrm{~m} / \mathrm{g}$ of coconut fiber yarn that was visually cohesive and presented low pilosity. The small average increase in tenacity and decrease in elongation of Group 2 fibers was harmless for the twisting performance. The present study implemented a cotton yarn as a warp that was stable enough to avoid disruptions during the weaving with the coconut fiber yarn made out of Group 2 fibers.

The woven yielded $20 \mathrm{~g}$ of a light textile fabric $(347 \mathrm{~g} / \mathrm{m} 2)$ and visually coarse. The coconut fiber textile proposed in this work requires further quality tests to identify its adequate applicability (e.g., geotextiles, industrial filters).

\section{CONCLUSION}

This study suggested an alternative for the recovery of coconut byproduct by employing coconut fibers in a textile application. Findings from this work have presented improvements in relation to the previous literature in two aspects: Firstly, statistical tests proved that the treatment proposed did not affect fibers quality. Secondly, the softening was effective enough to convert coconut fibers into continuous strands that enabled the spinning and weaving of the coconut fibers into a textile material. Thereby, this work provides valuable insights for the automation of coconut fiber spinning and the method can be employed to an extensive range of lignocellulosic fibers.

Some of the main challenges involved in the handling of coconut fiber for textile purposes are the 
higher lignin percentage in detriment of cellulose, which impacts on fiber's high stiffness; and the lack of cohesiveness in thickness and length, which hinders spinning procedures. This study corroborates the literature by demonstrating that besides elongation, softness and homogeneity are essential to enable coconut fiber spinning.

Future studies on coconut fiber for textile applications should focus on following topics: To evaluate whether the method proposed in this study is technologically feasible on an industrial scale, and its sustainability; compare the present study to other treatments that are more technologically advanced and environmentally friendly like plasma and enzyme-based ones; propose high added value textile materials by exploring multiple technical proprieties and applications for coconut fibers; and consider the possibility of producing artificial filaments from coconut byproduct biomass.

\section{ACKNOWLEDGMENTS}

We would like to thank the Coordenação de Aperfeiçoamento de Pessoal de Nível Superior for their financial support, the University of São Paulo, Centro Universitário da FEI, Pós-coco Indústria for supplying coconut fibers, and Ms. Tioko Tomikawa for the spinning resources.

\section{BIBLIOGRAPHY}

[1] FAOSTAT, http://faostat3.fao.org/browse/Q/*/E . Accessed in March 2018.

[2] MARTINS, C. R., JUNIOR, L. A. J., Evolução da produção de coco no Brasil e o comércio internacional: panorama 2010, In: Documentos 164, Embrapa Tabuleiros Costeiros, Arcaju, SE, 2011.

[3] DA COSTA, C. R., RATTI, A., DEL CURTO. B., "Product development using vegetable fibers", International Journal of Design \& Nature and Ecodynamics, v. 9, n.3, pp. 237-244, 2014.

[4] MARTINS, A. P., SILVA, P. L. R., WATANABE, T., et al., "O problema do pós-consumo do coco no Brasil: alternativas e sustentabilidade”, Sustentabilidade em Debate, v.7, n. 1, pp. 44-57, 2016.

[5] NALDONY, P., FLORES-SAHAGUN, T.HS., SATYANARAIANA, K., G., "Effect of thetype off fiber (coconut, eucalyptus, or pine) and compatibilizer on the properties of extrudedcompositess of recycled high densitypolyethylenee", Journal of Composite Materials, v. 50, n. 1, pp. 45-56, Feb. 2015.

[6] LOMELI-RAMIREZ, MG., SATYANARAIANA, G.K., MANRIQUE-GONZALEZ, R., et al., "Biocomposites of cassava starch-greencoconut fiberr: Part ii- Structure and properties", Carbohydrate Polymers, v.102, pp. 576-583, Feb. 2014.

[7] NASCIMENTO, D.M., ALMEIDA, J.S., VALE, M.S., et al., “A comprehensive approach for obtaining cellulose nanocrystals from coconut fiber. Part I: Proposition oftechnologicall pathways", Industrial Crops and Products, v. 93, pp. 66-74, Dec. 2016.

[8] SUMI, S., UNNIKRISHNAN, N., MATHEW, L., "Durability studies of surface-modified coir geotextile",, Geotextiles and Geomembraness, v. 46, n. 6, pp. 699-706, Dec. 2018.

[9] CABRAL, M.M.S., ABUD, A.K.S., SILVA, C.E.F., et al., "Bioethanol production from coconut husk fiber”, Food Technology, v. 46, n. 10, pp. 1872-1877, Oct. 2016.

[10] FERREIRA, R.VP., SILVA, E.E., CANEVESI, R.L.S., et al., “Application of the coconut fiber in radioactive liquid waste treatment”, International Journal of Environmental Science and Technology, v. 15, n. 8, pp. 1629-1640, Sep. 2017.

[11] JOHARI, K., SAMAN, N., SONG, S.T., et al., "Study of $\mathrm{Hg}(\mathrm{II})$ removal from aqueous solution using lignocellulosic coconut fiber biosorbents: Equilibrium andkinetic evaluationn", Chemical Engineering Communications, v. 201, n. 9, pp. 1198-1220, Apr. 2014.

[12] CARIJÓ, O.A., LIZ, R. D. S., MAKISHIMA, N., "Fibra da casca do coco verde como substrato agrícola”, Horticultura Brasileira, v. 20, n. 4, pp. 533-535, 2002.

[13] THEMELIS, N.J., ULLOA, P.A., "Methane generation in landfills", Renewable Energy, v. 32, n. 7, pp.1243-1257, 2006.

[14] UNIVERSIDADE DE SÃO PAULO - USP. SOUZA, M.A., MARTINS, A. P., SANCHES, R.A., DA SILVA, P.L.R, Processo de Produção de Fios Tratados de Coco e Artigo Têxtil. BR n. 102014 015573-2, 18 June 2014. 
[15] VAN DAM, J.E.G., Coir processing technologies: improvement of drying, softening, bleaching and dyeing coir fibre/yarn and printing coir floor coverings, In: Technical Paper n. 6, Common Fund for Commodities.Amsterdamn, 2002.

[16] ENCYCLOPÆDIA BRITANNICA, http://global.britannica.com/EBchecked/topic/123794/coconutpalm . Accessed in November 2014.

[17] FERREIRA-LEITAO, V., GOTTSCHALK, L. M. F., FERRARA, M. A., et al., "Biomass residues in Brazil: availability and potential uses", Waste and Biomass Valorization, v. 1, n. 1, pp. 65-76, 2010.

[18] ROSA, M. D. F., BEZERRA, F. C., CORREIA, D., et al., Utilização da casca do coco como substrato agrícola, In: Documento 52, Embrapa, Fortaleza, CE, 2002.

[19] CRAWSHAW, H.G., 2002. Carpet manufacture, Chaucer Press Limited, 2002.

[20] SAVASTANO JR., H., AGOPYAN, V., "Transition zone studies of vegetable fiber-cement paste composites", Cement and concrete Composites, v. 21, n. 1, pp. 49-57, 1999.

[21] SILVEIRA, M.S., Aproveitamento das cascas de coco verde para prodçãoo de briquetes em Salvador. Master Dissertationn. Escola Politécnica Federal da Bahia, Salvador, BA, Brasil, 2008.

[22] VARMA, D.S., VARMA, M., VARMA, I.K., "Coir fibers: Part I: Effect of physical and chemical treatments on properties", Textile Research Journal, v. 54, n. 12, pp. 827-832, 1984.

[23] BARBOSA JR., V., RAMIRES, E.C., RAZERA, I.A.T., et al., "Biobased composites fromtanninnphenolic polymers reinforced with coir fibers", Industrial Crops and Products, v. 32, n. 3, pp. 305-312, 2010.

[24] SALAZAR, V.L.P. LEÃO, A.L., ROSA, D.S., et al., "Biodegradation of coir and sisal applied in the automotive Industry", Journal of Polymers and Environment, v. 19, n. 3, pp. 677-688, 2011.

[25] RAJAN, A., ABRAHAM, E., "Coir Fiber-Process and Opportunities: Part 1", Journal of Natural Fibers, v. 3, n. 4, pp. 29-41, 2008.

[26] MATHAI, P.M., "Coir”, In: FRANCK, R.R., (ed), Bast and other plant fibers. chapter 7, Cambridge, England, Woodhead Publishing Limited, 2005.

[27] SMITH, J.L., Textile Processing, Chandigarh, Abhishek Publications, 2009.

[28] SUESS, H.U., "Bleaching", Restaurator, v. 30, n. 4, pp. 245-279, 2010.

[29] SCHINDLER, W. D., HAUSER, P. J., Chemical finishing of textiles, Elsevier, 2004.

[30] RAJAN, A., SENAN, R.C., PAVITHRAN, et al.,"Biosoftening of coir using selected microorganisms", Bioprocess and Biosystems Engineering, v. 28, n. 3, pp.165-173, 2005.

[31] OLIVEIRA, D.M., CIOFFI, M.O.H., BENINI, KC.C.C., et al., "Effects of plasma treatment on the sorption properties of coconut fibers", In: Proceedings of the International Conference on Natural Fibers: Advanced Materials for a Greener World, pp. 357-364, Braga, Jun. 2017.

[32] FARIAS, JG. G., CAVALCANTI, R.C., CANABARRO, B.R., et al., "Surface lignin removal on coir fibers by plasma treatment for improved adhesion in thermoplastic starch composites", Carbohydrate Polymers, v.165, pp. 429-436, Jun. 2017.

[33] THIRTY-SEVEN FIVE, https://www.thirtysevenfive.com/who-we-are/, Accessed on March 2018.

[34] COSTA, S.M., MAZZOLA, P.G., SILVA, J.C., et al., "Use of sugar cane straw as a source of cellulose for textile fiber production", Industrial Crops and Products, v.42, pp. 189-194, 2013.

[35] INTERNATIONAL ORGANIZATION FOR STANDARDIZATION - ISO, Textiles - Standard Atmospheres for Conditioning and Testing, ISO 139:2005.

[36] BAYER FIBRAS 100\%, "Qualidade final: Algodão", Revista Bayer CropScience, pp. 3-4, 2005.

[37] INTERNATIONAL ORGANIZATION FOR STANDARDIZATION - ISO, Textile fibers - Determination of linear density - Gravimetric method and vibroscope method, ISO 1973:1995.

[38] AMERICAN SOCIETY FOR TESTING AND MATERIALS - ASTM, Standard Test Method for Mass per Unit Area (weight) of Fabric, ASTM D-3776-96, West Conshohocken, PA, USA. 1995.

[39] AMERICAN SOCIETY FOR TESTING AND MATERIALS - ASTM, Standard Test Methods for Tensile Properties of Singles Textile Fibers, ASTM D3822, West Conshohocken, PA, USA. 1995.

[40] DALLY, J.W., RILEY, W.F., MC CONNEL, K.G., Instrumentation for Engineering Measurements, 2 ed., New York, John Wiley \& Sons, 1993.

[41] MONTGOMERY, D.C., Design and analysis of experiments, New Jersey, John Wiley \& Sons Inc, 2009. 
[42] ROSA, M.F., MEDEIROS, E.S., MALMONGE, J.A., et al., "Cellulose nanowhiskers from coconut husk fibers: Effect of preparation conditions on their thermal and morphologicalbehaviorr", Carbohydratee Polymers, v. 81, n. 1, pp. 83-92, 2010.

[43] ARSYAD, M., WARDANA, IN.G., PRATIKTO, IRAWAN,Y.S., "The morphology of coconut fiber under chemical treatment", Revista Matéria, v.20, n.02, pp.169-177, 2015.

[44] PARRA, R., Ensaios químicos e físicos em fibras de coco, In: Report No.118 210-205, Instituto de Pesquisas Tecnonógicas, São Paulo, 2010.

[45] MANILAL, V.B., AJAYAN, M.S., SREELEKSHMI, S.V., "Characterization of surface-treated coir fiber obtained from environmetal friendly bioextraction", Journal of Natural Fibers, v.7, n.04, 2010.

[46] GOULART SILVA, G., DE SOUZA, D.A., MACHADO, J.C., et al., "Mechanical and thermal characterization of native brazilian coir fiber", Journal of Applied Polymer Science Geotechnical, v.76, 2000.

[47] GALANTI, A.V., MANTELL, C.L., Polypropylene Fibers and Films, New York, Plenum Press, 1965.

\section{ORCID}

Adriana Pacheco Martins

https://orcid.org/0000-0002-7780-0319

Regina Aparecida Sanches

https://orcid.org/0000-0003-2489-8540 